\title{
LASIK for hyperopia correction pos DSAEK(Descement Stripping Automated Endotelial Keratoplasty) \\ LASIK hipermetrópico pós-DSAEK (Descement Stripping Automated Endotelial Keratoplasty)
}

Antonio Carlos Manhas Meireles ${ }^{1}$, Samir Jacob Bechara², Eduardo Martines ${ }^{3}$

\begin{abstract}
DSAEK (Descemet stripping automated endothelial keratoplasty) is one of the options for corneal endothelium disease, which in some patients can result in a residual hyperopia after the procedure. Usually 6 to 12 months after corneal transplantation refraction is already stable. This report describes a therapeutic option used in a 54 years old patient with Fuchs' endothelial dystrophy submitted to cataract and corneal transplant that resulted in residual hyperopia, three years after the procedure the best corrected vision was 20/20 with a refraction of $+3.25-1.00\left(5^{\circ}\right)$ treated with Hyperopic - LASIK (Laser-assisted In Situ Keratomileusis) with satisfactory visual result.
\end{abstract}

Keywords: keratomieleusis, laser in situ; Corneal diseases; Descemet stripping endothelial keratoplasty/methods; _Case reports

\section{ReSUMO}

O DSAEK (Descemet stripping automated endotelial Keratoplasty) é um dos procedimentos de escolha para tratamento das doenças que acometem o endotélio corneano. Apesar do sucesso terapêutico, o procedimento pode induzir uma hipermetropia residual. Em média a refração se estabiliza em um perído que varia de 6 a 12 meses após o transplante. O objetivo desse relato é descrever a evolução dessa opção terapêutica utilizada em um paciente de 54 anos portador de Distrofia de Fuchs. O paciente foi submetido ao transplante de córnea (DSAEK) e a remoção do cristalino no mesmo tempo cirúrgico o que resultou em hipermetropia residual. Após 3 anos de acompanhamento apresentava-se com a melhor visão corrigida de 20/20 (Snellen) no olho operado com uma refração de $+3,25-1,00\left(5^{\circ}\right)$. Optou-se por realização de LASIK (Laser assisted in situ Keratomileusis) hipermetrópico, obtendo um resultado visual satisfatório.

Descritores: Ceratomieleuse assistida por eximer laser in situ; Doenças da córnea; Ceratoplastia endotelial com remoção da lâmina limitante posterior; Relatos de casos

\footnotetext{
1 Setor de Cirurgia Refrativa, Ocular Surgery Center, São Paulo, SP, Brazil.

2 Setor de Cirurgia Refrativa do Hospital das Clínicas, Faculdade de Medicina, Universidade de São Paulo, São Paulo, SP, Brazil.

${ }^{3}$ Setor de Córnea e Cirurgia Refrativa, Ocular Surgery Center, São Paulo, SP, Brazil.
}

The authors declare no conflicts of interests.

Received for publication 09/02/2015 - Accepted for publication 22/09/2015 


\section{INTRODUCTION}

D SAEK (Descemet stripping automated endothelial Keratoplasty) is one of the procedures of choice for the treatment of diseases that affect the corneal endothelium. The advantages compared to penetrating keratoplasty are numerous, such as: faster visual rehabilitation, more predictability and less induction and regularity in the postoperative astigmatism. As a disadvantage, however, many works observe the occurrence of residual hypermetropia after DSAEK, often attributed to the tissue donor. ${ }^{(1-4)}$

Although the corneal curvature is minimally affected, there might be induction of a residual astigmatism attributed to the posterior curvature of the donor lamella. The refraction tends to become stable after 6-12 months after surgery. ${ }^{(4,5)}$

The aim of the present study is to report the case of a patient submitted to DSAEK which developed with residual astigmatism and hyperopia, with a LASIK (laser-assisted in-situ keratomileusis) being performed for residual ametropy correction.

\section{Case RePort}

Male patient, 54 years, referred to the cornea department of the Ocular Surgery Center (SP) with a diagnosis of Fuchs endothelial dystrophy and bilateral cataracts. The best corrected vision was 20/80 (Snellen) in the RE and 20/60 (Snellen) in the LE, with the following refraction: RE - $4.75-1.75\left(15^{\circ}\right)$ LE -2.00 $-1.50\left(155^{\circ}\right)$. On the occasion, biomicroscopy evidenced bilateral nuclear cataract, cornea guttata in both eyes, and the retinal mapping did not show changes.

A combined procedure was carried out in the RE: phacoemulsification, IOL implantation and DSAEK at the same surgical time, with no complications. The 1-piece Tecnis ${ }^{\circledR}$ lens (IOL - AMO) was implanted in intra-capsular position. DSAEK was performed without complications. The donor button is trepanned with a diameter of $8.50 \mathrm{~mm}$ and centrally positioned to the cornea with aid of an air bubble at the end of surgery.

One after the procedure, the patient showed a vision of 20/ $20 \mathrm{RE}$, with a refraction of $+3.50-1.00\left(5^{\circ}\right)$, keeping the contralateral eye without changes. (Figure 1).

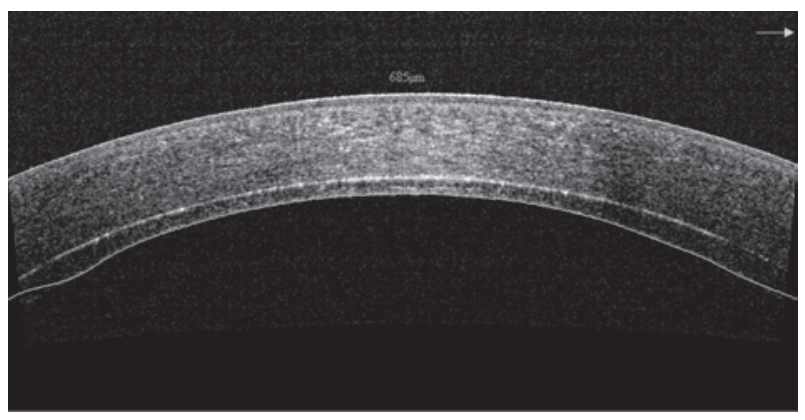

Figure 1: Corneal OCT 1 month after DSAEK, central thickness of 685 micron.

The postoperative period was uneventful, and after 10 months the vision remained stable and 20/20 RE, with 3.25 + refraction-1.00 $\left(5^{\circ}\right)$. However, there was refractive worsening and increase of patient complaints regarding the LE: corrected vision of $20 / 80$, with refraction of $-3.25-1.75\left(140^{\circ}\right)$.
After 1 year and 6 months of the combined procedure in the RE, the same approach of phacoemulsification and DSAEK was performed in the LE.

After the first postoperative month in the LE, the patient examination presented the following corrected vision and refraction: $+0.75-1.00\left(150^{\circ}\right), 20 / 20$.

After 3 years of follow-up in the RE and 2 years in the LE, the patient remained with stable visual acuity and refraction, but complaining of anisometropia and difficulty to wear glasses, being proposed the treatment of the RE with LASIK.

A H-LASIK was performed, as well as a programmed correction of $+3.25-1.00\left(5^{\circ}\right)$ using the Swind Amaris ${ }^{\circledR}$ platform. The preoperative (Figure 2) and postoperative (Figure 3) topographies, as well as the final result illustrated by OCT after laser treatment (Figure 4), showed the good development of the case.

A month after surgery, the patient presented vision of 20/ 20 in both eyes, and a refraction of: $+0.50-1.00$ (5) RE and +0.25 $-1.25\left(140^{\circ}\right) \mathrm{LE}$.

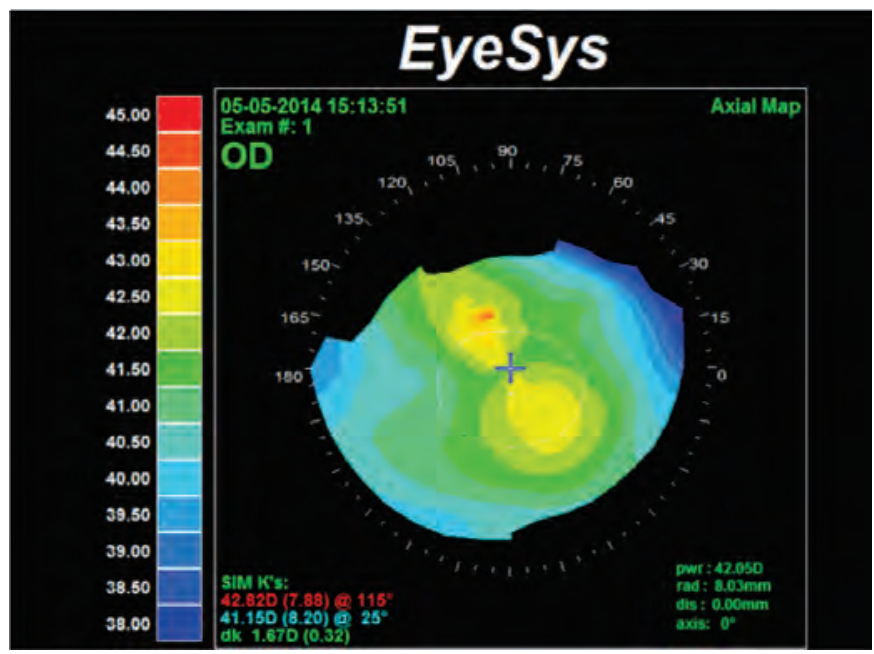

Figure 2: Pre-ablation corneal topography with excimer

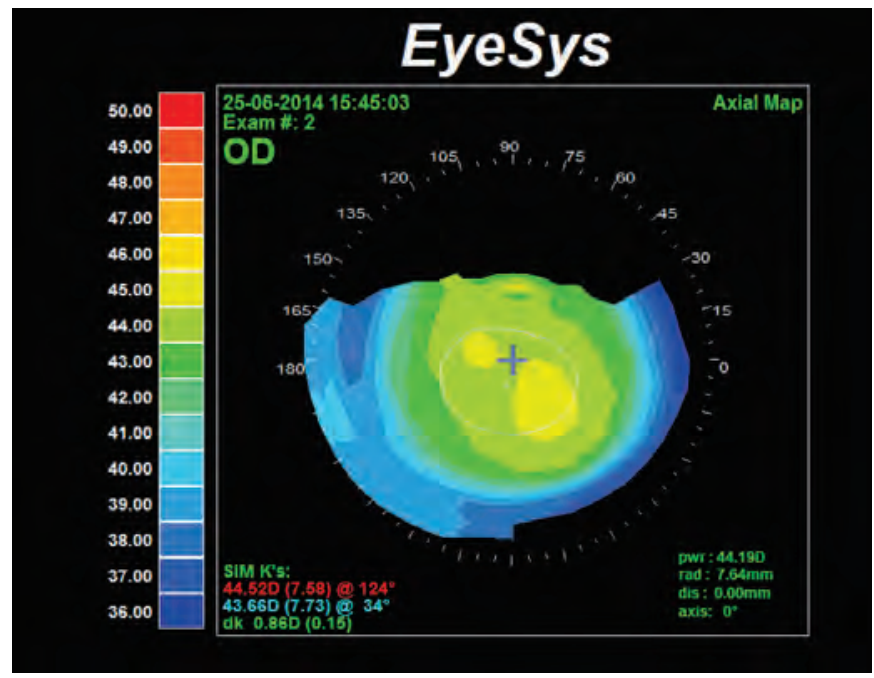

Figure 3: Corneal topography 1 month after ablation with excimer 


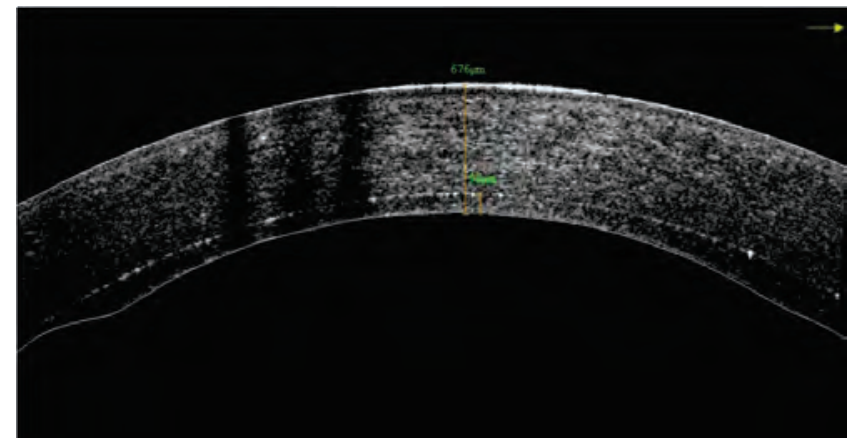

Figure 4: Corneal OCT 1 month after ablation with excimer, central thickness of 676 micron.

\section{Discussion}

Over the years, the endothelial transplant has gained a lot of space in the treatment of endothelial pathologies, especially when compared to penetrating transplants, with DSAEK being one of the techniques of choice. The combined treatment of phacoemulsification and DSAEK allows faster visual rehabilitation and better results than the penetrating transplant combined with phacoemulsification. However, the patient may still manifest residual hyperopia, as in the case in question. ${ }^{(2,3)}$

Another possibility of residual ametropy could be with the use of contact lenses, although the tolerance decreases with age. Other treatment options would be exchanging the intraocular lens, or even the implant of other lens, in piggy-back. However, any new intraocular procedure can promote endothelial loss or even precipitate a rejection, which decreases its use in the clinical practice. ${ }^{(3,4)}$

The correction of ametropias after penetrating transplants with laser, either using LASIK or even PRK (Photorefractive Keratectomy), are effective options, especially those that present bigger spherical components.

It is important to stress that no loss of endothelial cells was observed in the treatment of patients after penetrating transplants who had LASIK, which suggests its safety for use in patients after endothelial transplant. ${ }^{(6)}$

Recently, a number of cases reported by Ratanasit and Gorovoy was published using the LASIK and PRK after DSAEK for the treatment of ametropias in 5 patients. The authors obtained good refractive results after treatment, with no case of rejection being described, nor the need for retreatment postoperative follow-up for 30 months. $^{(4)}$
Our patient did not present transplant failure, rejection, or even refractive instability after the procedure on a 6-month followup after LASIK. In the present report, LASIK has proven effective in reducing the ametropy of the patient by reducing the complaints of anisometropia and discomfort with the use of optical correction.

Other reports corroborate that the treatment of the residual ametropias post DSAEK with LASIK are safe. However, larger periods of follow-up studies should be conducted to evaluate the refractive stability and the long-term effectiveness. It is important to note that in the event of changing the posterior lamella, the refractive error is not predictable, and a refractive retreatment may be necessary, and possibly a more complex than the first one.

\section{ReFERENCES}

1. Price MO, Price FW Jr. Descemet's stripping with endothelial keratoplasty: comparative outcomes with microkeratome - dissected and manually dissected donor tissue. Ophthalmology. 2006;13(11):1936-42.

2. Gorovoy MS. Descemet-stripping automated endothelial keratoplasty. Cornea. 2006;25(8):886-9.

3. Fung SS, Iovieno A, Shanmuganathan V, Maurino V. Femtosecond laser refractive surgery after descemet stripping - automated endothelial keratoplasty. Case Rep Ophthalmol Med. 2012; 2012:190953.

4. Ratanasit A, Gorovoy MS. Laser-Assisted In Situ Keratomileusis or Photorefractive Keratectomy After Descemet Stripping Automated Endothelial Keratoplasty. Cornea. 2011;30(7):787-9.

5. Chen ES, Terry MA, Shamie N, Hoar KL, Friend DJ. Stability of hyperopic refractive shift following Descemet-stripping automated endothelial keratoplasty.J Cataract Refract Surg. 2009;35(8):1473.

6. Barequet IS, Hirsh A, Levinger S. Femtosecond thin-flap LASIK for the correction of ametropia after penetrating keratoplasty. J Refract Surg. 2010;26(3):191-6.

\section{Corresponding author:}

Ocular Surgery Center

Antonio Carlos Manhas Meireles, R Afonso Celso N 1043 Vila Mariana São Paulo, ZIP Code 04119-061,

E-mail: meirelesacm@yahoo.com.br 